\title{
IMPLEMENTASI TEAMS GAMES TOURNAMENTS BERBANTUAN \\ MEDIA UNTUK MENINGKATKAN HASIL BELAJAR DAN \\ SIKAP TERHADAP PEMBELAJARAN IPS
}

\author{
Eva Fahmadia JM dan Mukminan \\ SMPN 1 Tempuran Magelang, Universitas Negeri Yogyakarta \\ evamaulida87@yahoo.co.id,_mukminan@yahoo.co.id
}

\begin{abstract}
Abstrak
Penelitian ini bertujuan meningkatkan (1) hasil belajar, dan (2) sikap terhadap pembelajaran IPS. Subjek penelitian adalah 30 peserta didik kelas VIIIF SMPN 1 Tempuran, Magelang tahun pelajaran 2013/2014. Teknik pengumpulan data menggunakan observasi, kuesioner, tes, dokumentasi dan catatan lapangan. Teknik analisis data menggunakan deskriptif komparatif. Hasil penelitian: (1) Rata-rata hasil belajar kognitif siklus I 78,67 meningkat menjadi 80,17 pada siklus II, dan 80,34 pada siklus III. Ketuntasan klasikal hasil belajar kognitif siklus I 70,00\% meningkat menjadi 86,21\% pada siklus II, dan 86,67\% pada siklus III. Rata-rata hasil belajar psikomotorik siklus I 88,33 meningkat menjadi 88,62 pada siklus II, dan 89,33 pada siklus III. Ketuntasan klasikal hasil belajar psikomotorik siklus I 80,00\% meningkat menjadi $86,21 \%$ pada siklus II, dan 86,67\% pada siklus III. (2) Rata-rata sikap terhadap pembelajaran IPS siklus I 72,99 meningkat menjadi 73,85 pada siklus II, dan 73,96 pada siklus III. Ketuntasan klasikal siklus I 90,00\% meningkat menjadi 93,10\% pada siklus II, dan 93,33\% pada siklus III.
\end{abstract}

Kata Kunci: Teams Games Tournaments, media, hasil belajar, sikap

\begin{abstract}
This study aims to improve (1) the learning achievement, and (2) the attitude to the Social Studies. The subject was 30 students of class VIII F, State Junior High School 1 Tempuran, Magelang in 2013/2014. The data collection techniques used were observation, questionnaire, test, documentation, and field note. The data analysis technique used was descriptive comparative. The result is as follows. (1) The overall mean of cognitive learning achievement increased from 78.67 in the first cycle to 80.17 in the second cycle, and 80.34 in the third cycle. The classical passing grade of cognitive learning achievement increased from $70.00 \%$ in the first cycle to $86.21 \%$ in the second cycle, and $86.67 \%$ in the third cycle. The overall mean of psycomotor learning achievement increased from 88.33 in the first cycle to 88.62 in the second cycle, and 89.33 in the third cycle. The classical passing grade of psycomotor learning achievement increased from $80.00 \%$ in the first cycle to $86.21 \%$ in the second cycle, and $86.67 \%$ in the third cycle. (2) The overall mean of the attitude to the Social Studies increased from 72.99 in the first cycle to 73.85, and 73.96 in the third cycle. The classical passing grade increased from $90.00 \%$ in the first cycle to $93.10 \%$ in the second cycle, and $93.33 \%$ in the third cycle.
\end{abstract}

Keywords: Teams Games Tournaments, Social Studies, media, learning achievement, attitude. 


\section{Pendahuluan}

Peraturan Pemerintah Republik Indonesia Nomor 32 Tahun 2013 tentang Perubahan Atas Peraturan Pemerintah Nomor 19 Tahun 2005 tentang Standar Nasional Pendidikan Pasal 19 menyebutkan bahwa proses pembelajaran pada satuan pendidikan diselenggarakan secara interaktif, inspiratif, menyenangkan, menantang dan memotivasi peserta didik untuk berpartisipasi aktif. Proses pembelajaran juga diharapkan dapat memberikan ruang yang cukup bagi prakarsa, kreativitas, dan kemandirian sesuai dengan bakat, minat dan perkembangan fisik serta psikologis peserta didik. Melalui proses pembelajaran yang demikian diharapkan peserta didik akan semakin termotivasi dalam belajar, daya kreativitasnya semakin meningkat, sikapnya semakin positif, serta semakin bertambah jenis pengetahuan dan keterampilan yang dikuasai.

Pada pembelajaran Ilmu Pengetahuan Sosial (IPS) di kelas VIIIF SMPN 1 Tempuran Magelang, model pembelajaran yang digunakan guru kurang bervariasi dan belum banyak menggunakan media pembelajaran. Proses pembelajaran yang terjadi banyak berpusat pada guru, sehingga keterampilan kerjasama antar peserta didik dan keterlibatan peserta didik dalam pembelajaran IPS rendah. Hal tersebut dapat mengakibatkan proses pembelajaran IPS menjadi membosankan dan kurang menyenangkan sehingga sikap peserta didik terhadap pembelajaran IPS rendah.

IPS di tingkat SMP meliputi kajian tentang ilmu ekonomi, sejarah, geografi dan sosiologi. Peserta didik menganggap materi pada pembelajaran IPS terlalu banyak dan penuh dengan hafalan. Peserta didik merasa seolah-olah mempelajari sesuatu yang tidak ada kaitannya dengan kehidupan sehari-hari. Peserta didik menghafal konsep-konsep yang tidak tahu penerapannya dan beranggapan bahwa apa yang dipelajari di IPS tidak ada kaitannya dengan kehidupan sehari-hari. Hal-hal tersebut dapat menyebabkan IPS menjadi suatu mata pelajaran yang tidak disukai peserta didik dan seolah menjadi nomor dua untuk ditekuni. Apalagi mata pelajaran IPS tidak termasuk mata pelajaran dalam Ujian Nasional, sehingga peserta didik beranggapan mata pelajaran IPS kurang penting sehingga motivasi dalam belajar IPS menjadi rendah. Kurangnya motivasi belajar peserta didik dalam proses pembelajaran dapat mengakibatkan proses belajar kurang optimal sehingga tujuan pembelajaran tidak tercapai.

Hasil belajar IPS peserta didik di kelas VIII F belum optimal. Hasil belajar IPS peserta didik belum seluruhnya mencapai Kriteria Ketuntasan Minimal (KKM) yang telah ditetapkan untuk mata pelajaran IPS tahun pelajaran 2013/2014, yaitu sebesar 75 . Rata-rata hasil ulangan harian kelas VIII F adalah 75,4. Dari 30 peserta didik, yang mencapai KKM mata pelajaran IPS sebesar 14 peserta didik atau 46,67\%. Sedangkan 16 peserta didik belum mencapai KKM, yaitu sebesar 53,33\%. Berdasarkan data tersebut, maka diperlukan upaya untuk meningkatkan hasil belajar IPS.

Pembelajaran dengan model kooperatif (cooperative learning) diharapkan dapat menjadi salah satu alternatif. Arends \& Kilcher (2010: p.306) menyatakan bahwa "cooperative learning is a teaching model or strategy that is characterizedby cooperative task, goal, and reward structures, and requires students to be actively engaged in discussion, debate, tutoring, and teamwork". Pembelajaran kooperatif adalah model pembelajaran atau strategi yang dicirikan adanya tugas kelompok, tujuan, dan struktur penghargaan, serta memaksimalkan peserta didik terlibat secara aktif dalam diskusi, debat, latihan, dan kerja sama tim.

Menurut Slavin (1990: p.2), pembelajaran kooperatif dapat digunakan secara efektif pada setiap tingkatan kelas dan untuk mengajarkan berbagai macam mata pelajaran. Mulai dari matematika, menulis sampai pada ilmu pengetahuan ilmiah, mulai dari kemampuan dasar sampai pemecahan masalah-masalah yang kompleks. Santrock (2009: p.61) menyatakan bahwa pembelajaran kooperatif bisa menjadi strategi yang efektif untuk meningkatkan prestasi. Sedangkan menurut Arend (2012: p.361), cooperative learning dapat menguntungkan bagi peserta didik yang berprestasi rendah maupun tinggi yang mengajarkan tugas akademik bersama-sama. Peserta didik yang berprestasi tinggi mengajari teman-temannya yang berprestasi lebih rendah, sehingga memberikan bantuan khusus dari sesama temannya. Melalui pembelajaran kooperatif diharapkan peserta didik lebih aktif menyalurkan pengetahuan, gagasan dan menerima gagasan dari temannya. 
Salahsatu teknik dalammodel pembelajaran kooperatif adalah Teams Games Tournaments (TGT). Slavin (1990: p.84) menyatakan bahwa "Teams Games Tournaments is the same as STAD in every respect but one: instead of the quizes and the individual improvement score system, TGT uses academic tournament". Maksud dari pernyataan tersebut adalah TGT sama dengan Student Team Achievement Division (STAD), tetapi menggantikan kuis dengan turnamen, dimana peserta didik memainkan game akademik dengan anggota tim lain untuk menyumbangkan poin bagi skor timnya. Sedangkan komponenkomponen dalam TGT adalah sebagai berikut (Slavin, 1990: p.84): 1) presentasi kelas, 2) tim, 3) game (permainan), 4) turnamen, dan 5) rekognisi tim.

Salah satu keunggulan dalam TGT adalah menggunakan permainan yang dapat disesuaikan dengan topik apapun. Peserta didik memainkan game (permainan) akademik. Peserta didik yang berprestasi rendah dan yang berprestasi tinggi mempunyai kesempatan yang sama untuk sukses (Slavin, 1990: p.6). Smaldino (2008: p.30) juga menyampaikan bahwa permainan dapat menciptakan lingkungan kompetitif dan harus mengikutiaturan yang telah ditetapkan. Permainan merupakan teknik yang sangat memotivasi, terutama untuk konten yang membosankan dan repetitif. Banyak kelebihan dalam menggunakan permainan pada proses pembelajaran, di antaranya menurut Sadiman dkk (2011: p.7881) adalah: 1) permainan adalah sesuatu yang menyenangkan untuk dilakukan dan sesuatu yang menghibur, 2) permainan memungkinkan adanya partisipasi aktif dari peserta didik untuk belajar, 3) permainan dapat memberikan umpan balik langsung, 4) permainan memungkinkan penerapan konsep-konsep ataupun peran-peran ke dalam situasi dan peranan yang sebenarnya di masyarakat, 5) permainan bersifat luwes, dan 6) permainan dapat dengan mudah dibuat dan diperbanyak.

Selain menggunakan permainan, TGT juga menggunakan turnamen. Silberman (2010: p.169) menyatakan bahwa turnamen pembelajaran adalah teknik menggabungkan kelompok belajar dengan kompetensi tim. Cara tersebut dapat digunakan untuk meningkatkan pembelajaran beragam fakta, konsep, bahkan keterampilan. Dengan turnamen, peserta didik dapat lebih bersemangat dan termotivasi dalam proses pembelajaran.

Selain model pembelajaran, penggunaan media yang bervariasi dalam proses pembelajaran IPS juga mempunyai pengaruh positif. Definisi media menurut Smaldino (2008: p.9) adalah "Media, the prural of medium, are means of communication. Derived from the Latin medium ("between"), theterm referstoanythingthatcarries information between a source and a receiver. Pernyataan tersebut mengandung arti bahwa media merupakan bentuk jamak dari perantara (medium) yang berarti sarana komunikasi. Berasal dari bahasa Latin medium yang berarti antara, istilah ini merujuk pada apa saja yang membawa informasi antara sebuah sumber dan sebuah penerima. Dalam hubungannya dengan pembelajaran, Gbamanja (Adekola, 2010: p.64) menyatakan bahwa: ...instructional media as any device with instructional content or function that is used for teaching purpose, including books, supplementary reading materials, audio-visual and other sensory materials, scripts for radio and television instruction, programme for computermanaged sets of materials for construction and manipulation. Pernyataan tersebut mengandung arti bahwa media pembelajaran adalah setiap alat yang berisi materi pembelajaran yang dapat digunakan untuk menyampaikan tujuan pembelajaran, mencakup buku, bahan bacaan pendukung, audio visual, skrip radio dan televisi, serta program komputer yang diatur untuk menyampaikan materi pembelajaran.

Media mempunyai peran penting dalam proses pembelajaran. Gafur (2012: p.106-107) menyatakan bahwa proses pembelajaran pada dasarnya sama dengan proses komunikasi, yaitu proses beralihnya pesan dari suatu sumber, menggunakan saluran, kepada penerima, dengan tujuan untuk menimbulkan akibat atau hasil. Dalam proses pembelajaran, pesan berupa materi pelajaran, sumber diperankan oleh guru, saluran berupa media, penerima adalah peserta didik, sedangkan hasil berupa bertambahnya pengetahuan, sikap dan keterampilan.

Selain untuk memperjelas materi pembelajaranagar tidakterlalubersifat verbalistik, Sadiman dkk (2011: p.17) menyatakan bahwa penggunaan media dalam proses pembelajaran secara tepat dan bervariasi dapat berguna untuk menimbulkan kegairahan belajar. Indriana (2011: 
p.47) juga menyatakan bahwa media berfungsi mengarahkan peserta didik memperoleh berbagai pengalaman belajar (learning experience). Media yang tepat dan sesuai dengan tujuan belajar akan mampu meningkatkan pengalaman belajar peserta didik sehingga peserta didik dapat meningkatkan hasil belajar. Sedangkan manfaat media pembelajaran secara umum menurut Solihatin \& Raharjo (2009: p.23-25) adalah untuk memperlancar interaksi antara guru dengan peserta didik sehingga kegiatan pembelajaran lebih efektif dan efisien.

Penggunaan model pembelajaran kooperatif teknik TGT disertai media diharapkan dapat meningkatkan hasil belajar dan sikap peserta didik terhadap pembelajaran IPS. Pengertian hasil belajar menurut Kennedy, Hyland \& Ryan (2012: p.5) adalah "Learning outcomes are statements of what a learner is expected to know, understand and/or be able to demonstrate after completion of a process of learning". Pernyataan tersebut mengandung arti bahwa hasil belajar adalah pernyataan yang dapat digunakan untuk mengetahui pemahaman dan kemampun peserta didik setelah selesainya proses pembelajaran.

Sudjana (2005: p.22) menyatakan bahwa sistem pendidikan nasional menggunakan klasifikasi hasil belajar dari Benyamin Bloom yang secara garis besar terbagi menjadi tiga ranah. Ketiga ranah tersebut adalah kognitif, psikomotorik dan afektif. Hasil belajar kognitif berkenaan dengan hasil belajar intelektual. Menurut Anderson \& Krathwohl (2010: p.99128) aspek dalam ranah kognitif adalah sebagai berikut: a) remember (mengingat), b) understand (memahami), c) apply (menerapkan), d) analyze (menganalisis), e) evaluate (mengevaluasi), dan f) create (mencipta).

Hasil belajar psikomotorik berkenaan dengan hasil belajarketerampilan dan kemampuan bertindak (Sudjana, 2005: p.23). Menurut Purwanto (2011: p.53), taksonomi hasil belajar psikomotorik yang paling banyak digunakan adalah taksonomi hasil belajar psikomotorik dari Simpson. Hasil belajar psikomotorik tersebut meliputi perception (persepsi), set (kesiapan), guided respons (gerakan terbimbing), mechanism (gerakan terbiasa), adaptation (gerakan kompleks) dan origination (kreativitas).

Tipe hasil belajar afektif tampak pada peserta didik dalam berbagai tingkah laku seperti perhatiannya terhadap pelajaran, disiplin, motivasi belajar, menghargai guru, teman kelas, kebiasaan belajar dan hubungan sosial (Sudjana, 2005: p.30). Krathwohl (Purwanto, 2011: p.5152) membagi hasil belajar afektif menjadi lima tingkat yaitu receiving (penerimaan), responding (partisipasi), valuing (penilaian), organization (organisasi) dan characterization (internalisasi).

Ada empat aspek dari ranah afektif yang bisa dinilai di sekolah, yaitu sikap, minat, percaya diri dan nilai (Mardapi, 2012: p.151). Menurut Nitko \& Brookhart (2011: p.451), "attitudes are characteristics of person that describe their positive and negative feelings toward particular objects, situations, institutions, persons or ideas. "Sikap adalah karakteristik seseorang yang menggambarkan perasaan positif dan negatif mereka terhadap objek, situasi, institusi, orang atau ide tertentu. Sedangkan Fishbein dan Ajzen (Mardapi, 2012: p.146) menyatakan bahwa sikap adalah suatu predisposisi yang dipelajari untuk merespon secara positif atau negatif terhadap suatu objek, situasi, konsep atau orang.

Winkel (2005: p.382) menyatakan bahwa sikap merupakan sesuatu yang bersifat agak kompleks, yang mengandung beberapa komponen atau aspek pokok, yaitu aspek kognitif, aspek afektif dan aspek konatif. Widoyoko (2009: 114-115) juga menyampaikan bahwa sikap mengandung tiga komponen, yaitu kognisi, afeksi, dan konasi. Kognisi berhubungan dengan pengetahuan, pemahaman maupun keyakinan tentang suatu objek. Afeksi berkenaan dengan perasaan terhadap suatu objek. Konasi berkenaan dengan kecenderungan bertingkah laku terhadap suatu objek. Sikap peserta didik terhadap pembelajaran IPS merupakan perasaan positif atau negatif peserta didik terhadap pembelajaran IPS. Sikap peserta didik terhadap pembelajaran penting untuk ditingkatkan. Sikap peserta didik terhadap pembelajaran harus lebih positif setelah peserta didik mengikuti pembelajaran.

Beberapa penelitian tentang penggunaan TGT berbantuan media dalam pembelajaran yaitu penelitian Anak Agung Gede Ngurah (2005), Sri Widarwati (2007), Puji Rahayu (2011), Suranto (2011) dan Ika Puspita (2011). Berdasarkan beberapa penelitian tersebut, penggunaan model pembelajaran kooperatif teknik TGT dengan menggunakan media terbukti dapat meningkatkan hasil belajar dan sikap peserta didik terhadap pembelajaran. 
Tujuan penelitian ini adalah untuk meningkatkan : 1) hasil belajar IPS, dan 2) sikap peserta didik kelas VIII F SMPN 1 Tempuran Magelang tahun pelajaran 2013/2014 terhadap pembelajaran IPS melalui implementasi TGT berbantuan media.

\section{Metode Penelitian}

Penelitian ini adalah penelitian tindakan kelas dengan model Kemmis \& Taggart. Penelitian dilaksanakan pada bulan September 2013 sampai dengan bulan November 2013 Subjek penelitian adalah peserta didik kelas VIII F SMPN 1 Tempuran Kabupaten Magelang tahun pelajaran 2013/2014 yang berjumlah 30 orang.

Teknik pengumpulan data pada penelitian ini meliputi: (1) kuesioner untuk mendapatkan data tentang sikap peserta didik terhadap pembelajaran IPS, (2) obervasi untuk mendapatkan data tentang keterlaksanaan proses pembelajaran dan hasil belajar psikomotorik, (3) tes untuk mendapatkan data tentang hasil belajar kognitif, (4) dokumentasi, dan (5) catatan lapangan.

Validitas instrumen yang digunakan dalam penelitian ini adalah validitas isi. Validitas isi instrumen dilakukan melalui professional judgment dengan cara sebagai berikut: (a) Konsultasi dengan Pembimbing, Instrumen dikonsultasikan kepada pembimbing.; (b) Konsultasi dengan Tim Ahli, Instrumen dimintakan judgment ahli kepada tim ahli yang direkomendasi oleh pembimbing.

Teknik analisis data dilakukan secara deskriptif komparatif.

Tindakan yang dilakukan dalam penelitian ini menggunakan model pembelajaran kooperatif teknik TGT dengan bantuan media. Tindakan dilakukan berdasarkan komponen-komponen TGT dengan menggunakan media yaitu:

Presentasi kelas.

Materi pembelajaran disampaikan oleh guru dengan cara presentasi di dalam ruang. Presentasi dilakukan dengan menggunakan media berupa hand out dan power point. Materi yang disampaikan dalam penelitian ini adalah K.D. 2.1 yaitu menjelaskan proses perkembangan kolonialisme dan imperialisme Barat, serta pengaruh yang ditimbulkannya di berbagai daerah dan K.D. 2.2 yaitu menguraikan proses terbentuknya kesadaran nasional, identitas
Indonesia dan perkembangan pergerakan kebangsaan Indonesia.

Tim.

Guru membagi peserta didik dalam beberapa tim. Tim terdiri dari empat atau lima peserta didik yang mewakili seluruh bagian dari kelas dalam hal kemampuan akademik, jenis kelamin, agama dan ras. Di dalam tim, peserta didik belajar bersama dan bekerja sama dalam memainkan game dan mengikuti turnamen.

Game (permainan).

Game terdiri atas materi-materi yang kontennya relevan dan dirancang untuk menguji pengetahuan peserta didik yang diperolehnya dari presentasi kelas dan pelaksanaan kerja tim. Dalam penelitian ini, game menggunakan bantuan media berupa kartu. Adapun media kartu yang digunakan dalam game adalah Pasangan Kartu, Kartu Terpilih dan Kartu Bernomor.

Turnamen.

Turnamen dilakukan setelah guru memberikan presentasi di kelas dan tim telah melaksanakan kerja kelompok. Kompetisi dibuat seimbang berdasarkan prestasi peserta didik.

Rekognisi Tim.

Tim akan mendapatkan penghargaan apabila skor rata-rata mereka mencapai skor tertinggi.

\section{Hasil Penelitian dan Pembahasan}

Tindakan pada penelitian ini terdiri atas tiga siklus. Masing-masing siklus terdiri atas dua pertemuan. Siklus pertama dilaksanakan pada tanggal 2 Oktober 2013 dan 3 Oktober 2013. Siklus kedua dilaksanakan pada tanggal 23 Oktober 2013 dan 24 Oktober 2013. Siklus ketiga dilaksanakan pada tanggal 6 Nopember 2013 dan 7 Nopember 2013. Tindakan pada masingmasing pertemuan terdiri atas empat tahap, yaitu perencanaan, pelaksanaan, observasi dan refleksi.

Hasil Siklus I

Hasil belajar ranah kognitif pada siklus I menunjukkan nilai terendah yang diperoleh peserta didik adalah 45 dan nilai tertinggi adalah 95. Terdapat satu peserta didik yang mendapatkan nilai $25-49,8$ peserta didik mendapatkan nilai 50-74 dan 21 peserta didik mendapatkan nilai 75-100. Nilai rata-rata kelas pada siklus I sebesar 78,67 dan ketuntasan klasikal sebesar 70,00\%. 
Hasil belajar ranah psikomotorik pada siklus I menunjukkan nilai terendah yang diperoleh peserta didik adalah 70 dan nilai tertinggi adalah 100. Terdapat 6 peserta didik yang mendapatkan nilai 50-74 dan 24 peserta didik yang mendapatkan nilai 75-100. Nilai rata-rata kelas pada siklus I sebesar 88,33 dan ketuntasan klasikal sebesar 80,00 \%.

Sikap terhadap pembelajaran pada siklus I menunjukkan nilai terendah yang diperoleh peserta didik adalah 64,58 dan nilai tertinggi adalah 81,25 . Terdapat 3 peserta didik yang mendapatkan nilai $>$ 55-70 atau kategori Cukup dan 27 peserta didik mendapatkan nilai $>70-85$. Nilai rata-rata kelas pada siklus I sebesar 72,99 dan ketuntasan klasikal sebesar 90,00\%.

\section{Hasil Siklus II}

Hasil belajar ranah kognitif pada siklus II menunjukkan nilai terendah yang diperoleh peserta didik adalah 65 dan nilai tertinggi adalah 95. Terdapat 4 peserta didik mendapatkan nilai 50-74 dan 25 peserta didik mendapatkan nilai 75100. Nilai rata-rata kelas pada siklus II sebesar 80,17 dan ketuntasan klasikal sebesar 86,21\%.

Hasil belajar ranah psikomotorik pada siklus II menunjukkan nilai terendah yang diperoleh peserta didik adalah 60 dan nilai tertinggi adalah 100 . Terdapat 4 peserta didik yang mendapatkan nilai $50-74$ dan 25 peserta didik yang mendapatkan nilai $75-100$. Nilai rata-rata kelas pada siklus II sebesar 88,62 dan ketuntasan klasikal sebesar 86,21 \%.

Sikap terhadap pembelajaran pada siklus II menunjukkan nilai terendah yang diperoleh peserta didik adalah 65,63 dan nilai tertinggi adalah 83,33. Terdapat 2 peserta didik yang mendapatkan nilai $>55-70$ atau kategori Cukup dan 27 peserta didik mendapatkan nilai $>70$ 85 atau kategori Baik. Nilai rata-rata kelas pada siklus II sebesar 73,85 dan ketuntasan klasikal sebesar $93,10 \%$.

\section{Hasil Siklus III}

Hasil belajar ranah kognitif pada siklus III menunjukkan nilai terendah yang diperoleh peserta didik adalah 50 dan nilai tertinggi adalah 90. Terdapat 4 peserta didik mendapatkan nilai
50-74 dan 26 peserta didik mendapatkan nilai 75100. Nilai rata-rata kelas pada siklus III sebesar 80,34 dan ketuntasan klasikal sebesar 86,67\%.

Hasil belajar ranah psikomotorik pada siklus III menunjukkan nilai terendah yang diperoleh peserta didik adalah 60 dan nilai tertinggi adalah 100 . Terdapat 4 peserta didik yang mendapatkan nilai 50-74 dan 26 peserta didik yang mendapatkan nilai 75-100. Nilai rata-rata kelas pada siklus III sebesar 89,33 dan ketuntasan klasikal sebesar 86,67\%.

Sikap terhadap pembelajaran pada siklus III menunjukkan nilai terendah yang diperoleh peserta didik adalah 66,67 dan nilai tertinggi adalah 83,33 . Terdapat 2 peserta didik yang mendapatkan nilai $>$ 55-70 atau kategori Cukup dan 28 peserta didik mendapatkan nilai $>70$ 85 atau kategori Baik. Nilai rata-rata kelas pada siklus III sebesar 73,96 dan ketuntasan klasikal sebesar 93,33\%.

\section{Rekapitulasi Data Hasil Penelitian}

Rekapitulasi persebaran perolehan hasil belajar ranah kognitif peserta didik dari siklus I sampai siklus III disajikan dalam tabel berikut:

Tabel 1. Rekapitulasi Persebaran Hasil Belajar Ranah Kognitif

\begin{tabular}{|c|c|c|c|}
\hline \multirow{2}{*}{$\begin{array}{c}\text { Rentang } \\
\text { Nilai }\end{array}$} & \multicolumn{3}{|c|}{ Persentase Perolehan Peserta Didik } \\
\cline { 2 - 4 } & Siklus I & Siklus II & Siklus III \\
\hline $00-24$ & 0,00 & 0,00 & 0,00 \\
$25-49$ & 3,33 & 0,00 & 0,00 \\
$50-74$ & 26,67 & 13,79 & 13,33 \\
$75-100$ & 70,00 & 86,21 & 86,67 \\
\hline
\end{tabular}

Berdasarkan tabel 1 dapat diketahui bahwa peserta didik yang hasil belajar ranah kognitifnya mendapatkan nilai 25 - 49 hanya terdapat pada siklus I yaitu sebesar 3,33 \%. Peserta didik yang mendapatkan nilai 50 - 74 pada siklus I sebesar $26,67 \%$, pada siklus II sebesar $13,79 \%$ dan pada siklus III sebesar $13,33 \%$. Peserta didik yang mendapatkan nilai 75 - 100 pada siklus I sebesar $70,00 \%$, pada siklus II sebesar 86,21 \% dan pada siklus III sebesar $86,67 \%$. Persebaran hasil belajar ranah kognitif tersebut dapat digambarkan sebagai berikut: 


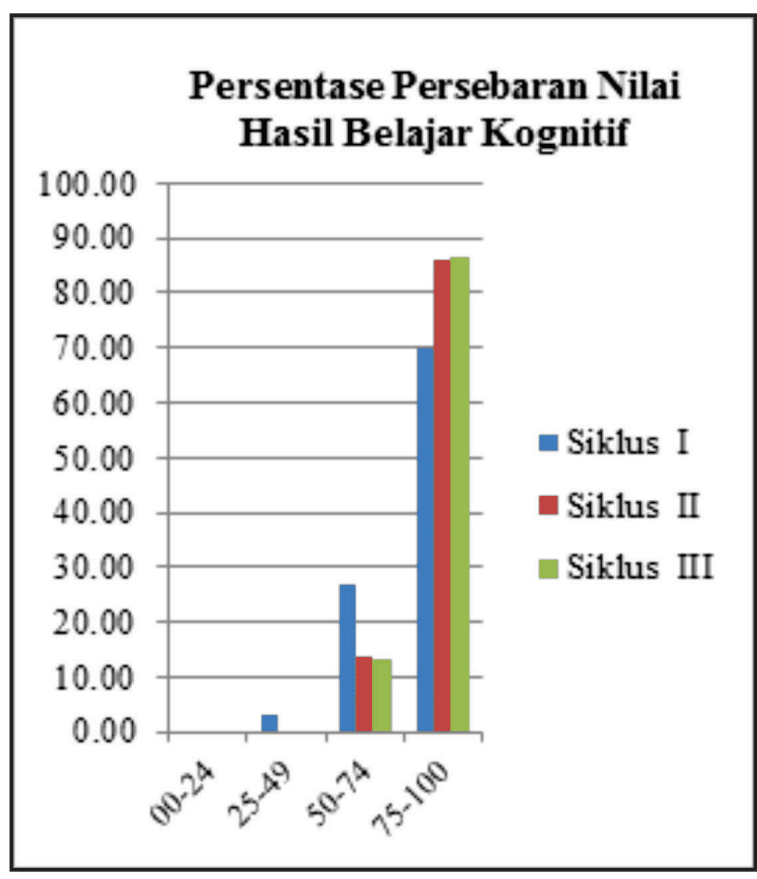

Gambar 1. Diagram Persentase Persebaran Hasil Belajar Ranah Kognitif

Rekapitulasi rata-rata kelas dan persentase ketuntasan klasikal hasil belajar ranah kognitif disajikan dalam tabel berikut:

Tabel 2. Rekapitulasi Hasil Belajar Ranah Kognitif

\begin{tabular}{|l|c|c|}
\hline Uraian & $\begin{array}{c}\text { Rata-Rata } \\
\text { Kelas }\end{array}$ & $\begin{array}{c}\text { Persentase Ketuntasan } \\
\text { Klasikal }\end{array}$ \\
\hline Siklus I & 78,67 & 70,00 \\
Siklus II & 80,17 & 86,21 \\
Siklus III & 80,34 & 86,67 \\
\hline
\end{tabular}

Grafik rata-rata kelas hasil belajar ranah kognitif dapat digambarkan sebagai berikut:

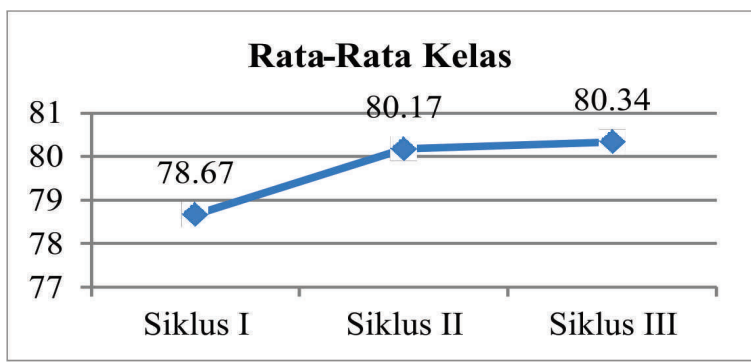

Gambar 2. Grafik Rata-Rata Kelas Hasil Belajar Ranah Kognitif

Grafik persentase ketuntasan klasikal ranah kognitif dapat digambarkan sebagai berikut:

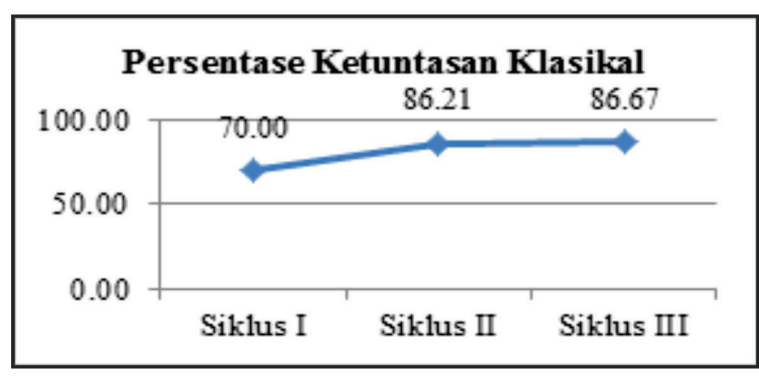

Gambar 3. Grafik Ketuntasan Klasikal Hasil Belajar Ranah Kognitif

Persebaran hasil belajar ranah psikomotorik disajikan pada tabel berikut:

Tabel 3. Rekapitulasi Persebaran Hasil Belajar Ranah Psikomotorik

\begin{tabular}{|c|c|c|c|}
\hline \multirow{2}{*}{$\begin{array}{c}\text { Rentang } \\
\text { Nilai }\end{array}$} & \multicolumn{3}{|c|}{ Persentase Perolehan Peserta Didik } \\
\cline { 2 - 4 } & Siklus I & Siklus II & Siklus III \\
\hline $00-24$ & 0,00 & 0,00 & 0,00 \\
$25-49$ & 0,00 & 0,00 & 0,00 \\
$50-74$ & 20,00 & 13,79 & 13,33 \\
$75-100$ & 80,00 & 86,21 & 86,67 \\
\hline
\end{tabular}

Berdasarkan tabel 3 dapat diketahui bahwa peserta didik yang hasil belajar ranah psikomotoriknya mendapatkan nilai $50-74$ pada siklus I sebesar 20,00 \%, pada siklus II sebesar 13,79 \% dan pada siklus III sebesar $13,33 \%$. Peserta didik yang mendapatkan nilai 75 - 100 pada siklus I sebesar 80,00\%, pada siklus II sebesar $86,21 \%$ dan pada siklus III sebesar 86,67\%. Rekapitulasi persebaran hasil belajar psikomotorik tersebut dapat digambarkan sebagai berikut:

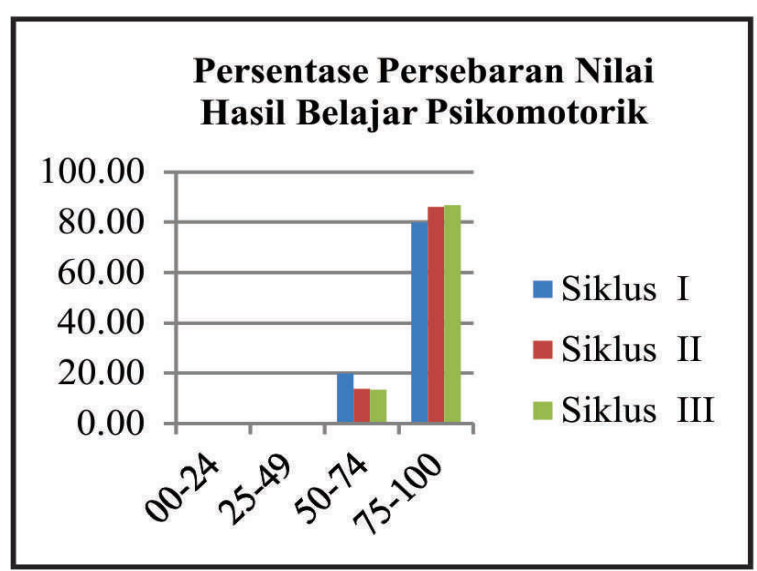

Gambar 4. Diagram Persentase Persebaran Nilai Hasil Belajar Ranah Psikomotorik

Rekapitulasi rata-rata kelas dan ketuntasan klasikal hasil belajar ranah psikomotorik disajikan pada tabel berikut: 
Tabel 4. Rekapitulasi Hasil Belajar Ranah Psikomotorik

\begin{tabular}{|l|c|c|}
\hline \multicolumn{1}{|c|}{ Uraian } & $\begin{array}{c}\text { Rata-Rata } \\
\text { Kelas }\end{array}$ & $\begin{array}{c}\text { Persentase } \\
\text { Ketuntasan } \\
\text { Klasikal }\end{array}$ \\
\hline Siklus I & 88,33 & 80,00 \\
\hline Siklus II & 88,62 & 86,21 \\
\hline Siklus III & 89,33 & 86,67 \\
\hline
\end{tabular}

Grafik peningkatan rata-rata kelas hasil belajar ranah psikomotorik dapat digambarkan sebagai berikut:

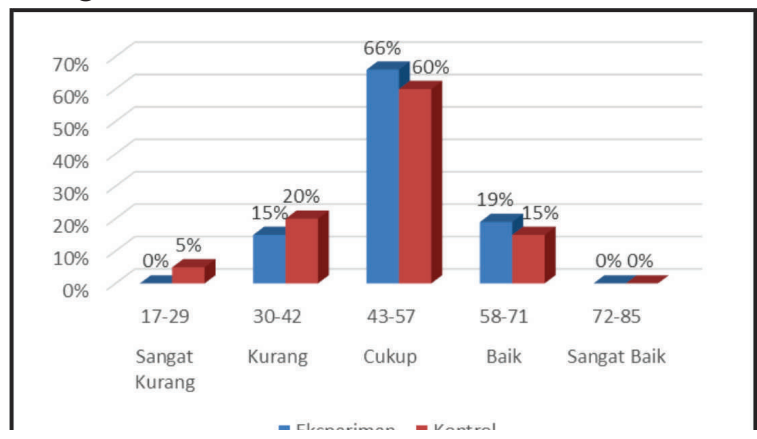

Gambar 5. Grafik Rata-Rata Kelas Hasil Belajar Ranah Psikomotorik

Grafik peningkatan persentase ketuntasan klasikal hasil belajar ranah psikomotorik dapat digambarkan sebagai berikut:

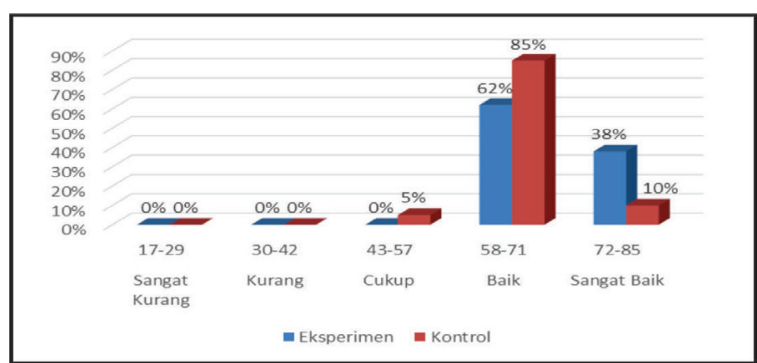

Gambar 6. Grafik Ketuntasan Klasikal Hasil Belajar Ranah Psikomotorik

Rekapitulasi persebaran sikap terhadap pembelajaran disajikan pada tabel berikut:

Tabel 5. Rekapitulasi Persebaran Nilai Sikap terhadap Pembelajaran

\begin{tabular}{|c|c|c|c|c|}
\hline \multirow{2}{*}{ Nilai } & \multirow{2}{*}{ Kategori } & \multicolumn{3}{|c|}{$\begin{array}{c}\text { Persentase Perolehan } \\
\text { Peserta Didik }\end{array}$} \\
\cline { 3 - 5 } & & $\begin{array}{c}\text { Siklus } \\
\text { I }\end{array}$ & $\begin{array}{c}\text { Siklus } \\
\text { II }\end{array}$ & $\begin{array}{c}\text { Siklus } \\
\text { III }\end{array}$ \\
\hline$>85$ & Sangat Baik & 0,00 & 0,00 & 0,00 \\
\hline$>70-85$ & Baik & 90,00 & 93,10 & 93,33 \\
\hline$>55-70$ & Cukup & 10,00 & 6,90 & 6,67 \\
\hline$>40-55$ & Kurang & 0,00 & 0,00 & 0,00 \\
\hline$\leq 40$ & Sangat Kurang & 0,00 & 0,00 & 0,00 \\
\hline
\end{tabular}

Berdasarkan tabel 5 dapat diketahui bahwa peserta didik yang sikap terhadap pembelajarannya mendapatkan nilai $>55-70$ atau kategori Cukup pada siklus I sebesar 10,00 $\%$, pada siklus II sebesar $6,90 \%$ dan pada siklus III sebesar $6,67 \%$. Peserta didik yang mendapatkan nilai $>70-85$ atau berkategori Baik pada siklus I sebesar 90,00\%, pada siklus II sebesar 93,10\% dan pada siklus III sebesar 93,33\%. Rekapitulasi persebaran sikap terhadap pembelajaran tersebut dapat digambarkan sebagai berikut:

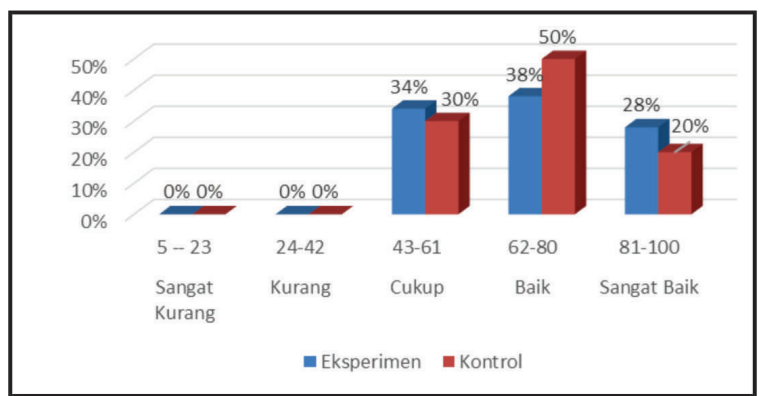

Gambar 7. Diagram Persentase Persebaran Sikap terhadap Pembelajaran

Rekapitulasi nilai rata-rata kelas dan ketuntasan klasikal sikap terhadap pembelajaran disajikan pada tabel berikut:

Tabel 6. Rekapitulasi Sikap terhadap Pembelajaran

\begin{tabular}{|l|c|c|}
\hline \multicolumn{1}{|c|}{ Uraian } & $\begin{array}{c}\text { Rata-Rata } \\
\text { Kelas }\end{array}$ & $\begin{array}{c}\text { Persentase } \\
\text { Ketuntasan } \\
\text { Klasikal }\end{array}$ \\
\hline Siklus I & 72,99 & 90,00 \\
\hline Siklus II & 73,85 & 93,10 \\
\hline Siklus III & 73,96 & 93,33 \\
\hline
\end{tabular}

Grafik rata-rata kelas sikap terhadap pembelajaran dapat digambarkan sebagai berikut:

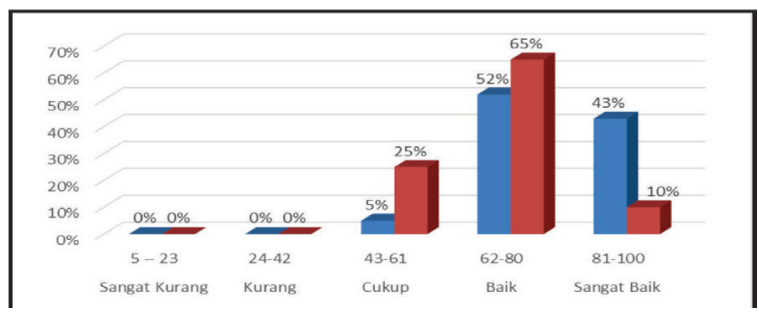

Gambar 8. Grafik Rata-Rata Kelas Sikap terhadap Pembelajaran

Grafik persentase ketuntasan klasikal sikap terhadap pembelajaran dapat digambarkan sebagai berikut: 
Game dan turnamen mendorong peserta didik bersemangat dalam mengikuti proses pembelajaran. Konten dalam game dan turnamen yang disesuaikan dengan materi yang sedang dipelajari, mampu membuat peserta didik belajar dengan asyik. Suasana pembelajaran saat dilaksanakannya game dan turnamen sangat menggairahkan. Game dan turnamen juga membantu peserta didik merasa senang sehingga proses pembelajaran menjadi menyenangkan.

Game dan turnamen menuntut setiap peserta didik aktif mengikuti semua proses pembelajaran dengan seksama. Tahapan yang dimulai dengan presentasi dari guru hingga turnamen, harus melibatkan peserta didik baik sebagai individu maupun sebagai bagian dari tim. Semua peserta didik tertantang untuk mensukseskan tim baik dalam game maupun dalam turnamen. Suasana itu menjadi mengasyikkan karena penuh nuansa tantangan dan persaingan yang positif.

Media yang digunakan dalam implementasi TGT mampu menarik perhatian peserta didik. Media yang digunakan dalam penyampaian materi pembelajaran maupun dalam game dan turnamen mampu membuat proses pembelajaran menjadi lebih menarik. Media hand out, power point, serta gabungan hand out dan power point menarik dan mengarahkan perhatian peserta didik untuk berkonsentrasi pada isi pembelajaran . Peserta didik yang awal pembelajaran kurang tertarik dengan materi pelajaran, tetapi dengan penggunaan media peserta didik dapat tertarik sehingga kemungkinan untuk memperoleh dan mengingat isi pelajaran semakin besar. Pasangan kartu, kartu terpilih dan kartu bernomor yang digunakan dalam game dan turnamen juga menarik perhatian peserta didik. Kartu yang didesain dengan warna-warni dan gambargambar, sangat membantu peserta didik merasa asyik dengan proses pembelajaran yang terjadi.

Penggunaan media dalam pembelajaran juga dapat meningkatkan ranah afektif peserta didik. Fungsi afektif ini dapat terlihat dari tingkat kenikmatan peserta didik ketika belajar teks yang bergambar. Gambar atau lambang visual dapat menggugah emosi dan sikap peserta didik, misalnya gambar tentang penderitaan rakyat Indonesia akibat kebijakan kolonialisme Barat dan gambar tentang perlawanan rakyat melawan kolonialisme Barat. 
Pembelajaran dengan TGT menjadi menarik karena ada suasana baru yang membuat peserta didik bersemangat. Media yang dibuat bervariasi pada setiap siklus juga menarik dan mengundang perhatian peserta didik untuk tahu. Ada stimulus yang mendorong peserta didik termotivasi meningkatkan kemampuannya memahami materi pembelajaran. Turnamen melahirkan konsekuensi adanya kompetisi secara terbuka. Kompetisi inilah yang mendorong peserta didik merasa harus aktif mengikuti seluruh proses pembelajaran dan memahami materi pembelajaran dengan baik. Pada akhirnya, hasil belajar peserta didik dapat meningkat.

Peningkatan hasil belajar peserta didik dapat diketahui dari peningkatan hasil belajar ranah kognitif dan psikomotorik. Berdasarkan persebaran hasil belajar ranah kognitif dapat diketahui bahwa peserta didik yang hasil belajar ranah kognitifnya mendapatkan nilai 25 - 49 hanya terdapat pada siklus I yaitu sebesar 3,33 $\%$. Peserta didik yang mendapatkan nilai 50 74 pada siklus I sebesar $26,67 \%$, pada siklus II sebesar 13,79 \% dan pada siklus III sebesar 13,33 $\%$. Peserta didik yang mendapatkan nilai 75 100 pada siklus I sebesar 70,00 \%, pada siklus II sebesar 86,21 \% dan pada siklus III sebesar $86,67 \%$. Hal tersebut menunjukkan terdapat peningkatan untuk hasil belajar ranah kognitif peserta didik yang mendapatkan nilai $75-100$. Peningkatan dari siklus I ke siklus II sebesar $16,21 \%$ dan peningkatan dari siklus II ke siklus III sebesar $0,46 \%$.

Peningkatan hasil belajar ranah kognitif juga dapat dilihat berdasarkan nilai rata-rata kelas dan ketuntasan klasikal. Rata-rata kelas siklus I sebesar 78,67, siklus II sebesar 80,17 dan siklus III sebesar 80,34. Berdasarkan ratarata kelas tiap siklus, peningkatan rata-rata kelas dari siklus I ke siklus II adalah sebesar 1,50, sedangkan peningkatan rata-rata kelas dari siklus II ke siklus III sebesar 0,17. Ketuntasan klasikal siklus I sebesar 70,00 \%, siklus II sebesar 86,21 $\%$ dan siklus III sebesar $86,67 \%$. Berdasarkan ketuntasan klasikal tersebut, peningkatan ketuntasan klasikal dari siklus I ke siklus II adalah sebesar $16,21 \%$, sedangkan peningkatan ketuntasan klasikal dari siklus II ke siklus III sebesar $0,46 \%$.

Peningkatan hasil belajar peserta didik selain terjadi pada ranah kognitif, juga terjadi pada ranah psikomotorik. Berdasarkan persebaran hasil belajar ranah psikomotorik dapat diketahui bahwa peserta didik yang hasil belajar ranah psikomotoriknya mendapatkan nilai 50 74 pada siklus I sebesar 20,00\%, pada siklus II sebesar 13,79 \% dan pada siklus III sebesar 13,33 $\%$. Peserta didik yang mendapatkan nilai $75-$ 100 pada siklus I sebesar $80,00 \%$, pada siklus II sebesar 86,21 \% dan pada siklus III sebesar $86,67 \%$. Hal tersebut menunjukkan terdapat peningkatan untuk hasil belajar psikomotorik peserta didik yang mendapatkan nilai $75-100$. Peningkatan dari siklus I ke siklus II sebesar 6,21 $\%$ dan peningkatan dari siklus II ke siklus III sebesar $0,46 \%$.

Peningkatan hasil belajar ranah psikomotorik dapat juga dilihat berdasarkan nilai rata-rata kelas dan ketuntasan klasikal. Rata-rata kelas siklus I sebesar 88,33, siklus II sebesar 88,62 dan siklus III sebesar 89,33. Berdasarkan rata-rata kelas tiap siklus, peningkatan rata-rata kelas dari siklus I ke siklus II adalah sebesar 0,29, sedangkan peningkatan rata-rata kelas dari siklus II ke siklus III sebesar 0,71. Ketuntasan klasikal siklus I sebesar 80,00 \%, siklus II sebesar 86,21 $\%$ dan siklus III sebesar 86,67\%. Berdasarkan ketuntasan klasikal tersebut, peningkatan ketuntasan klasikal dari siklus I ke siklus II adalah sebesar $6,21 \%$, sedangkan peningkatan ketuntasan klasikal dari siklus II ke siklus III sebesar $0,46 \%$.

Peningkatan juga terjadi pada sikap peserta didik terhadap pembelajaran. Berdasarkan persebaran sikap terhadap pembelajaran dapat diketahui bahwa peserta didik yang sikap terhadap pembelajaran mendapatkan nilai $>55$ - 70 atau kategori Cukup pada siklus I sebesar $10,00 \%$, pada siklus II sebesar $6,90 \%$ dan pada siklus III sebesar $6,67 \%$. Peserta didik yang mendapatkan nilai $>70-85$ atau berkategori Baik pada siklus I sebesar $90,00 \%$, pada siklus II sebesar 93,10 \% dan pada siklus III sebesar 93,33 \%. Hal tersebut menunjukkan terdapat peningkatan untuk sikap peserta didik terhadap pembelajaran yang mendapatkan nilai $>70-85$ atau berkategori Baik. Peningkatan dari siklus I ke siklus II sebesar 3,10 \% dan peningkatan dari siklus II ke siklus III sebesar 0,23\%.

Peningkatan sikap terhadap pembelajaran juga dapat dilihat berdasarkan nilai rata-rata kelas dan ketuntasan klasikal. Rata-rata kelas 
siklus I sebesar 72,99, siklus II sebesar 73,85 dan siklus III sebesar 73,96. Berdasarkan ratarata kelas tiap siklus, peningkatan rata-rata kelas dari siklus I ke siklus II adalah sebesar 0,86, sedangkan peningkatan rata-rata kelas dari siklus II ke siklus III sebesar 0,11. Ketuntasan klasikal siklus I sebesar 90,00\%, siklus II sebesar 93,10 $\%$ dan siklus III sebesar 93,33\%. Berdasarkan ketuntasan klasikal tersebut, peningkatan ketuntasan klasikal dari siklus I ke siklus II adalah sebesar 3,10\%, sedangkan peningkatan ketuntasan klasikal dari siklus II ke siklus III sebesar $0,23 \%$.

Berdasarkan rekapitulasi hasil belajar dan sikap terhadap pembelajaran, pembelajaran kooperatif teknik Teams Games Tournaments (TGT) dengan bantuan media terbukti dapat meningkatkan hasil belajar dan sikap terhadap pembelajaran IPS di kelas VIII F SMPN 1 Tempuran Magelang pada tahun pelajaran 2013/2014.

\section{Simpulan dan Saran}

\section{Simpulan}

Berdasarkan hasil penelitian dan pembahasan, maka dapat diambil simpulan sebagai berikut:

a. Pembelajaran kooperatif teknik TGT berbantuan media dapat meningkatkan hasil belajar IPS di kelas VIII F SMPN 1 Tempuran Magelang tahun pelajaran 2013/2014 baik pada ranah kognitif maupun psikomotorik. Rata-rata kelas hasil belajar kognitif pada siklus I sebesar 78,67 meningkat menjadi 80,17 pada siklus II dan 80,34 pada siklus III. Ketuntasan klasikal hasil belajar kognitif pada siklus I sebesar 70,00 \% meningkat menjadi 86,21 \% pada siklus II dan $86,67 \%$ pada siklus III. Rata-rata kelas hasil belajar psikomotorik pada siklus I sebesar 88,33 meningkat menjadi 88,62 pada siklus II dan 89,33 pada siklus III. Ketuntasan klasikal hasil belajar psikomotorik pada siklus I sebesar 80,00 \% meningkat menjadi 86,21 $\%$ pada siklus II dan $86,67 \%$ pada siklus III.

b. Pembelajaran kooperatif teknik TGT berbantuan media dapat meningkatkan sikap peserta didik terhadap pembelajaran IPS di kelas VIII F SMPN 1 Tempuran Magelang tahun pelajaran 2013/2014. Rata-rata kelas sikap terhadap pembelajaran pada siklus I sebesar 72,99 (kategori Baik) meningkat menjadi 73,85 (kategori Baik) pada siklus II dan 73,96 (kategori Baik) pada siklus III. Ketuntasan klasikal sikap terhadap pembelajaran pada siklus I sebesar 90,00\% meningkat menjadi $93,10 \%$ pada siklus II dan $93,33 \%$ pada siklus III.

\section{Saran}

Sebaiknya guru menerapkan model pembelajaran dan menggunakan media yang bervariasi dalam proses pembelajaran. Model pembelajaran kooperatif teknik TGT dengan bantuan media merupakan salah satu model pembelajaran yang dapat membuat proses pembelajaran menjadi lebih menarik, menyenangkan dan dapat meningkatkan hasil belajar serta sikap peserta didik terhadap pembelajaran. Kepada peneliti lain, disarankan agar hasil penelitian ini digunakan sebagai bahan kajian dan referensi dalam penelitian lanjutan serta dapat menjadi inspirasi dalam mengembangkan dan menciptakan model pembelajaran yang bermanfaat dalam pengembangan proses pembelajaran.

\section{Daftar Pustaka}

Adekola, G. (2010). The impact of instructional media on the education of youths on HIV/ AIDS in Nigeria urban comminities. International Journal of Scientific Research in Education, Juni 2010, Volume 3(1), 6472, dalam http://www.ijsre.com. Diakses pada hari Selasa tanggal 21 Januari 2014 pukul 17.40 WIB.

Anderson, L. W \& Krathwohl, D. R. (2010). Kerangka landasan untuk pembelajaran, pengajaran dan asesmen, revisi taksonomi pendidikan Bloom. (Terjemahan Agung Prihantoro). Yogyakarta: Pustaka Pelajar. (Buku asli diterbitkan tahun 2001).

Arends, R.I \& Kilcher, A. (2010). Teaching for student learning "becoming an accumplhised teacher". New York: Taylor $\&$ Francis e-Library.

Arends, Richard I. (2012). Learning to teach. Ninth edition. New York: The McGrawHill Companies, Inc.

Gafur, A. (2012). Desain pembelajaran: konsep, model, dan aplikasinya dalam perencanaan pelaksanaan pembelajaran. 
Yogyakarta: Penerbit Ombak.

Indriana, D. (2011). Ragam alat bantu media pengajaran. Yogyakarta: DIVA Press.

Kennedy, D, Hyland, A \& Ryan, N. (2012). Writing and using learning outcomes:a practical guide dalam http://sss.dcu.ie/ afi/docs/bologna/writing and using learning out comes.pdf. Diakses pada hari Jumat tanggal 28 Juni 2013 pukul 09.35 WIB.

Mardapi, D. (2012). Pengukuran, penilaian dan evaluasi pendidikan. Yogyakarta: Nuha Medika.

Ngurah, A.A.G. (2005). Implementasi model pembelajaran kooperatif tipe TGT dengan pendekatan pembelajaran kontekstual dan model evaluasinya dalam pembelajaran fisika di SMP tahun ajaran 2004/2005. Jurnal Ilmiah Pendidikan dan Pembelajaran Volume 2 Nomor 1, Desember 2005, 148 162.

Nitko, A. J. \& Brookhart, S. M. (2011). Educational assessment of students. Sixth edition. Boston: Pearson Education.

Peraturan Pemerintah Republik Indonesia Nomor 32 Tahun 2013 tentang Perubahan Atas Peraturan Pemerintah Nomor 19 Tahun 2005 tentang Standar Nasional Pendidikan.

Purwanto. (2011). Evaluasi hasil belajar. Yogyakarta: Pustaka Pelajar.

Puspita, I. (2011). Perbandingan keefektifan pembelajaran kooperatif tipe Teams Games Tournament dan Make a Match ditinjau dari prestasi belajar, sikap dan minat siswa terhadap matematika di SD kecamatan Depok. Tesis magister, tidak diterbitkan, Universitas Negeri Yogyakarta, Yogyakarta.

Rahayu, P. (2011). Peningkatan pemahaman menghitung keliling dan luas segi empat melalui pembelajaran kooperatif TGT pada siswa kelas VII SMP N 2 Klaten tahun 2010/2011. Metodika Jurnal Pendidikan Dasar Volume 1 Nomor 3, November 2011, 57-64.

Sadiman, A. S, dkk. (2011). Media pendidikan: pengertian, pengembangan dan pemanfaatannya. Jakarta: PT Raja Grafindo Persada.

Santrock, J. W. (2009). Psikologi pendidikan educational psychology. (Terjemahan Diana Angelica). Jakarta: Salemba Humanika.

Silberman, M. (2010). 101 ways to make training active, 101 cara pelatihan dan pembelajaran aktif. (Terjemahan Dani Dharyani). Jakarta: PT Indeks. (Buku asli diterbitkan tahun 2005).

Slavin, R. E. (1990). Cooperative learning "Theory, research and practice." Boston: Allyn and Bacon.

Smaldino, S. E., Lowther, D. L., Russell, J. D. (2008). Instructional technology and media for learning. Ninth Edision. New Jersey: Pearson Merill Prentice Hall.

Solihatin, E \& Raharjo. (2009). Cooperative learning. Analisis model pembelajaran IPS. Jakarta: PT Bumi Aksara.

Sudjana, N. (2005). Penilaian hasil proses belajar mengajar. Bandung: PT Remaja Rosdakarya.

Suranto. (2011). Peningkatan penguasaan materi bangun datar berbahasa Inggris dengan model pembelajaran teams games tournament (TGT) dan media kartu permainan matematika siswa kelas $7 F$ SMP Negeri 2 Kendal semester II tahun pelajaran 2010/2011. Metodika Jurnal Pendidikan Dasar Volume 1 Nomor 3, November 2011, 79-90.

Widarwati, Sri. (2007). Implementasi model pembelajaran teams games tournaments berbasis teknologi informasi pada perkuliahan kajian mode. Majalah Ilmiah Pembelajaran Nomor 2 Volume 3, Oktober 2007, 224-239.

Widoyoko, E. P. (2009). Evaluasi program pembelajaran, panduan praktis bagi pendidik dan calon pendidik. Yogyakarta: Pustaka Pelajar.

Winkel, W.S. (2005). Psikologi pengajaran. Jogjakarta: Media Abadi. 